\title{
Mandibular changes produced by functional appliances in Class II malocclusion: A systematic review
}

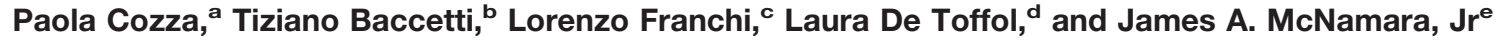 \\ Rome and Florence, Italy, and Ann Arbor, Mich
}

The aim of this systematic review of the literature was to assess the scientific evidence on the efficiency of functional appliances in enhancing mandibular growth in Class II subjects. A literature survey was performed by applying the Medline database (Entrez PubMed). The survey covered the period from January 1966 to January 2005 and used the medical subject headings (MeSH). The following study types that reported data on treatment effects were included: randomized clinical trials (RCTs), and prospective and retrospective longitudinal controlled clinical trials (CCTs) with untreated Class II controls. The search strategy resulted in 704 articles. After selection according to the inclusion/exclusion criteria, 22 articles qualified for the final analysis. Four RCTs and 18 CCTs were retrieved. The quality standards of these investigations ranged from low (3 studies) to medium/high (6 studies). Two-thirds of the samples in the 22 studies reported a clinically significant supplementary elongation in total mandibular length (a change greater than $2.0 \mathrm{~mm}$ in the treated group compared with the untreated group) as a result of overall active treatment with functional appliances. The amount of supplementary mandibular growth appears to be significantly larger if the functional treatment is performed at the pubertal peak in skeletal maturation. None of the 4 RCTs reported a clinically significant change in mandibular length induced by functional appliances; 3 of the 4 RCTs treated subjects at a prepubertal stage of skeletal maturity. The Herbst appliance showed the highest coefficient of efficiency (0.28 $\mathrm{mm}$ per month) followed by the Twin-block (0.23 mm per month). (Am J Orthod Dentofacial Orthop 2006;129:599.e1-599.e12)

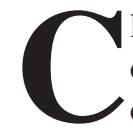
lass II malocclusion is one of the most common orthodontic problems, and it occurs in about one third of the population. ${ }^{1-3}$ The most consistent diagnostic finding in Class II malocclusion is mandibular skeletal retrusion. A therapy able to enhance mandibular growth is indicated in these patients. $^{4,5} \mathrm{~A}$ wide range of functional appliances aimed

aProfessor and head, Department of Orthodontics, University of Rome "Tor Vergata," Rome, Italy.

bAssistant professor, Department of Orthodontics, University of Florence, Florence, Italy; Thomas M. Graber Visiting Scholar, Department of Orthodontics and Pediatric Dentistry, School of Dentistry, University of Michigan, Ann Arbor.

${ }^{\mathrm{c}}$ Research associate, Department of Orthodontics, University of Florence, Florence, Italy; Thomas M. Graber Visiting Scholar, Department of Orthodontics and Pediatric Dentistry, School of Dentistry, University of Michigan, Ann Arbor.

dResearch fellow, Department of Orthodontics, University of Rome "Tor Vergata," Rome, Italy.

eThomas M. and Doris Graber Endowed Professor of Dentistry, Department of Orthodontics and Pediatric Dentistry, School of Dentistry; professor of Cell and Developmental Biology, School of Medicine; research professor, Center for Human Growth and Development, University of Michigan, Ann Arbor; private practice, Ann Arbor, Mich.

Reprint requests to: Lorenzo Franchi, Università degli Studi di Firenze, Via del Ponte di Mezzo, 46-48, 50127, Firenze, Italy; e-mail, t.baccetti@odonto.unifi.it. Submitted, June 2005; revised and accepted, November 2005. $0889-5406 / \$ 32.00$

Copyright (C) 2006 by the American Association of Orthodontists. doi:10.1016/j.ajodo.2005.11.010 to stimulate mandibular growth by forward posturing of the mandible is available to correct this type of skeletal and occlusal disharmony. ${ }^{5}$ Although many studies in animals have demonstrated that skeletal mandibular changes can be produced by posturing the mandible forward, ${ }^{6-8}$ the effects on humans are more equivocal and controversial. Many treatment protocols, sample sizes, and research approaches have led to disparate outcomes in studies on human subjects.

A previous systematic review on the efficacy of functional appliances on mandibular growth by Chen et $\mathrm{al}^{9}$ analyzed the relevant literature from 1966 to 1999 in a Medline search strategy limited to randomized clinical trials (RCTs). The results were inconclusive. The main difficulty when analyzing RCTs was related to inconsistencies in measuring treatment-outcome variables. In addition, treatment durations varied among studies, and treatment groups were compared with either untreated control groups or subjects undergoing other forms of treatment.

RCTs have been recommended as the standard for comparing alternative treatment approaches. To date, very few RCTs on treatment outcomes of functional jaw orthopedics have been published in the orthodontic literature. The difficulty in gathering many patients 
with a specific occlusion deviation, the ethical issue of leaving a group of patients untreated for a rather long time, and the fact that several items required in quality reviews ${ }^{10,11}$ obviously do not apply to orthodontics (eg, patients blinded or observer blinded to treatment) are substantial reasons for the paucity of RCTs in orthodontics. These considerations suggest that a rational systematic review should include longitudinal prospective and retrospective controlled clinical trials (CCTs) to broaden the scientific information about the treatment effects of orthodontic appliances. ${ }^{12}$ Furthermore, recent investigations on treatment outcomes of functional appliances should be examined to supplement the data analyzed by Chen et al. ${ }^{9}$ It is advisable also to limit the systematic review to clinical trials that compared treated Class II groups with matched untreated Class II samples. It has been demonstrated that mandibular growth in Class II subjects differs significantly from that of subjects with normal occlusion. ${ }^{13-15}$ Moreover, the selection of studies that used untreated Class II controls allows the assimilation of the outcomes of CCTs and RCTs, because they include by definition untreated controls with the same malocclusion types as the treated subjects.

This systematic review was undertaken to answer the question: "Does the mandible grow more in Class II subjects treated with functional appliances than in untreated Class II subjects?" Corollaries included "Is the average effect of functional appliances on mandibular length clinically significant?" and "Which functional appliances are more efficient?"

\section{MATERIAL AND METHODS}

\section{Search strategies}

The strategy for this systematic review was influenced mainly by the National Health Service Center for Reviews and Dissemination. ${ }^{16}$ To identify all studies that examined mandibular growth, a literature survey was carried out by applying the Medline database (Entrez PubMed, www.ncbi.nim.nih.gov). The survey covered the period from January 1966 to January 2005 and used the MeSH term "malocclusion, Angle Class II," which was cross-referenced with the MeSH term "functional, appliances." Additionally, a search in the Cochrane Clinical Trials Register (www.cochrane.org/ reviews) was performed.

\section{Selection criteria}

The inclusion and exclusion criteria are given in detail in Table I. The following study types that reported data on mandibular growth were included: RCTs, meta-analyses, CCTs, and prospective and retrospective longitudinal studies. The retrieved studies
Table I. Inclusion and exclusion criteria for retrieved studies

\begin{tabular}{ll}
\hline Inclusion criteria & Exclusion criteria \\
\hline $\begin{array}{c}\text { Meta-analyses, RCTs, } \\
\text { prospective and } \\
\text { retrospective CCTs }\end{array}$ & $\begin{array}{c}\text { Case reports, case series and } \\
\text { descriptive studies, review } \\
\text { Articles in English }\end{array}$ \\
articles published from & abstracts \\
January 1966 to January & Laboratory studies \\
2005 & Studies of adults \\
Studies of growing patients & Studies performed on magnetic \\
Studies conducted on lateral & resonance imaging \\
cephalograms including & Measurements of total \\
measurements of total & mandibular length using \\
mandibular length (using & point articulare \\
point condylion) & Treatment combined with \\
Untreated Class II control & extractions \\
subjects & Treatment combined with fixed \\
& appliances \\
& Surgical treatments \\
& Success of therapy (at occlusal \\
& and skeletal levels) as \\
& criterion for case selection \\
\hline
\end{tabular}

had to analyze cephalometrically the effects of functional therapy on mandibular dimensions (including total mandibular length measured by using the anatomical point condylion) with respect to untreated Class II controls. No restrictions were set for sample size. Articles written in English from January 1966 to January 2005 were included. Abstracts, laboratory studies, descriptive studies, case reports, case series, reviews and opinion articles were excluded.

\section{Data collection and quality analysis}

Data were collected on the following items for the retrieved studies: year of publication, study design, materials (study sample, control sample, type of functional appliance), age at the start of treatment, methods of measurement, appliance wear, treatment/observation duration, success rate, posttreatment observation, and authors' conclusions.

A quality evaluation of the methodological soundness of each article was performed for the RCTs according to the methods described by Jadad et al, ${ }^{11}$ with an extension of the quality appraisal to the CCTs. ${ }^{12}$ The following characteristics were used: study design, sample size and prior estimate of sample size, withdrawals (dropouts), method error analysis, blinding in measurements, and adequate statistics. The quality of the retrieved studies was categorized as low, medium, or high.

Two independent reviewers (T.B. and L.F.) assessed the articles separately. The data were extracted from each article without blinding to the authors, and 
intra-examiner conflicts were resolved by discussion of each article to reach a consensus.

\section{Analysis of reported outcomes}

To give the reader a quantitative appraisal of modifications in mandibular dimensions and sagittal position in Class II patients treated with functional appliances when compared with untreated Class II controls, the following data were evaluated for each retrieved study: mandibular sagittal position (SNB), total mandibular length (Co-Gn or $\mathrm{Co}-\mathrm{Pg}$ ), mandibular ramus height (Co-Go), and mandibular body length (Go-Gn, Go-Me, or Go-Pg). Studies that used articulare for the measurements of either mandibular length or ramus height were excluded, because that point is not an anatomical landmark that pertains to the mandible exclusively. ${ }^{9} \mathrm{Be}-$ cause most of the samples in the retrieved studies reported annualized mandibular changes (expressed as annualized mean differences between treated and untreated groups), annualization was applied to the data of the remaining samples (except for samples with a treatment duration that was too short for annualization-less than 9 months). The actual amount of supplementary elongation in total mandibular length after active treatment with the functional appliance was also analyzed.

It is well known that different functional appliances require different treatment durations to reach the goal of Class II correction at the occlusal level. Therefore, this review included an evaluation of both the effectiveness and the efficiency of different types of functional appliances in inducing a supplementary elongation of the mandible with respect to controls. Effectiveness can be defined as the ability of the appliance to induce a clinically significant supplementary elongation of the mandible with respect to the controls at the end of the overall treatment period. Because of the average number of patients enrolled in the examined studies (ie, to the power of the retrieved studies) ${ }^{17}$ clinical significance in mandibular dimensions was defined as at least a $2.0 \mathrm{~mm}$ difference between treated and untreated groups. Efficiency consists of an effective treatment in the shortest time. An appraisal of efficiency was performed by dividing the supplementary elongation of the mandible during the overall treatment period with the functional appliance by the number of months of active treatment duration (coefficient of efficiency).

\section{RESULTS}

The search strategy resulted in 704 articles. After selection according to the inclusion and exclusion
Table II. Articles included in review

\begin{tabular}{|c|c|}
\hline Articles & Study design \\
\hline Jakobsson $^{18}$ & $\mathrm{RCT}, \mathrm{L}$ \\
\hline Pancherz $^{19}$ & $\mathrm{P}, \mathrm{L}, \mathrm{CCT}$ \\
\hline McNamara et $\mathrm{al}^{20}$ & $\mathrm{R}, \mathrm{L}, \mathrm{CCT}$ \\
\hline Jakobsson and Paulin ${ }^{21}$ & $\mathrm{R}, \mathrm{L}, \mathrm{CCT}$ \\
\hline McNamara et $\mathrm{al}^{22}$ & $\mathrm{R}, \mathrm{L}, \mathrm{CCT}$ \\
\hline Windmiller $^{23}$ & $\mathrm{R}, \mathrm{L}, \mathrm{CCT}$ \\
\hline Nelson et $\mathrm{al}^{24}$ & RCT, L \\
\hline Tulloch et $\mathrm{al}^{25}$ & RCT, L \\
\hline Illing et $\mathrm{al}^{26}$ & $\mathrm{P}, \mathrm{L}, \mathrm{CCT}$ \\
\hline Franchi et $\mathrm{al}^{27}$ & $\mathrm{R}, \mathrm{L}, \mathrm{CCT}$ \\
\hline Tümer and Gültan ${ }^{28}$ & $\mathrm{R}, \mathrm{L}, \mathrm{CCT}$ \\
\hline Toth and McNamara ${ }^{29}$ & $\mathrm{R}, \mathrm{L}, \mathrm{CCT}$ \\
\hline Mills and McCulloch ${ }^{30}$ & $\mathrm{R}, \mathrm{L}, \mathrm{CCT}$ \\
\hline Baccetti et $\mathrm{al}^{31}$ & $\mathrm{R}, \mathrm{L}, \mathrm{CCT}$ \\
\hline Chadwick et $\mathrm{al}^{32}$ & $\mathrm{R}, \mathrm{L}, \mathrm{CCT}$ \\
\hline de Almeida et $\mathrm{al}^{33}$ & $\mathrm{R}, \mathrm{L}, \mathrm{CCT}$ \\
\hline Basciftci et $\mathrm{al}^{34}$ & $\mathrm{R}, \mathrm{L}, \mathrm{CCT}$ \\
\hline Pangrazio-Kulbersh et al ${ }^{35}$ & $\mathrm{R}, \mathrm{L}, \mathrm{CCT}$ \\
\hline Faltin et $\mathrm{al}^{36}$ & $\mathrm{R}, \mathrm{L}, \mathrm{CCT}$ \\
\hline Janson et $\mathrm{al}^{37}$ & $\mathrm{R}, \mathrm{L}, \mathrm{CCT}$ \\
\hline $\mathrm{O}^{\prime}$ Brien et $\mathrm{al}^{38}$ & $\mathrm{RCT}, \mathrm{L}$ \\
\hline Cozza et $\mathrm{al}^{39}$ & $\mathrm{R}, \mathrm{L}, \mathrm{CCT}$ \\
\hline
\end{tabular}

$\overline{R C T \text {, Randomized clinical trial; } L \text {, longitudinal study; } P \text {, prospective }}$ study; $C C T$, controlled clinical trial; $R$, restrospective study.

criteria (Table I), 22 articles qualified for the final analysis. ${ }^{18-39}$

\section{Study design}

The study designs of the 22 articles are shown in Table II, and the results of the review are summarized in Tables III and IV. The 22 articles included 4 RCTs, 2 prospective CCTs, and 16 retrospective CCTs. No meta-analysis was found.

\section{Quality analysis}

The analysis showed that research quality and methodological soundness was low in 3 studies, medium in 13 studies, and medium/high in 6 studies (Table IV). Withdrawals (dropouts) were declared in 5 studies, ${ }^{18,24-26,38}$ and, in these studies, the number of dropouts generally was low.

Three studies ${ }^{20,23,28}$ did not include a method error analysis, and 3 studies ${ }^{26,32,38}$ used blinding in measurements. Only 8 studies used proper statistical methods. $^{25-27,31,32,36,37,39}$ Thirteen studies ${ }^{18-24,28-30,33-35}$ applied parametric tests in samples that were not tested for normality, and 1 study ${ }^{38}$ did not evaluate statistically the changes in mandibular dimensions.

\section{Descriptive analysis of reported outcomes}

In this analysis, a distinction was made between statistically significant differences and clinically signif- 
Table III. Summarized data of 22 studies retrieved

\begin{tabular}{|c|c|c|c|c|}
\hline Article material & Controls & Age (y) & Methods/measurements & $\begin{array}{l}\text { Appliance wear } \\
\text { (h/day) }\end{array}$ \\
\hline Jakobsson $^{18}$ & \multirow[t]{3}{*}{ Karolinska Institutet, Sweden } & & \multirow[t]{3}{*}{ Cephalometric analysis } & \multirow[t]{3}{*}{11.5} \\
\hline 17 act & & 8.5 & & \\
\hline 17 contr & & 8.5 & & \\
\hline Pancherz ${ }^{19}$ & \multirow[t]{3}{*}{ University of Malmö, Sweden } & & Cephalometric analysis & \multirow[t]{3}{*}{ Full time } \\
\hline 22 Herbst & & 12 & Hand-wrist radiographs & \\
\hline 20 contr & & 11.1 & & \\
\hline McNamara et $\mathrm{al}^{20}$ & \multirow{5}{*}{$\begin{array}{l}\text { University of Michigan Elementary and } \\
\text { Secondary School Growth Study } \\
\text { (UMESSGS) }\end{array}$} & & \multirow[t]{5}{*}{ Cephalometric analysis } & \multirow[t]{5}{*}{18} \\
\hline 51 FR-2 early & & 8.8 & & \\
\hline 49 FR-2 late & & 11.6 & & \\
\hline $36 \mathrm{ECG}$ & & 8.4 & & \\
\hline 21 LCG & & 11 & & \\
\hline Jakobsson and Paulin ${ }^{21}$ & \multirow{5}{*}{$\begin{array}{l}\text { Orthodontic County Clinic, Östersund, } \\
\text { Sweden }\end{array}$} & & \multirow[t]{5}{*}{ Cephalometric analysis } & \multirow[t]{5}{*}{ Not declared } \\
\hline 22 act $\mathrm{M}$ & & 11.6 & & \\
\hline 31 act $\mathrm{F}$ & & 10.9 & & \\
\hline 28 contr $\mathrm{M}$ & & 10.5 & & \\
\hline 32 contr $F$ & & 10.4 & & \\
\hline McNamara et $\mathrm{al}^{22}$ & \multirow[t]{4}{*}{ UMESSGS } & & \multirow[t]{4}{*}{ Cephalometric analysis } & \multirow[t]{4}{*}{ Full time } \\
\hline 45 Herbst & & 12 & & \\
\hline 41 FR-2 & & 11.5 & & \\
\hline 21 contr & & 11 & & \\
\hline Windmiller $^{23}$ & \multirow[t]{3}{*}{ UMESSGS } & & Cephalometric analysis & \multirow{3}{*}{$\begin{array}{l}\text { Full time except for } \\
\text { meals }\end{array}$} \\
\hline 46 Herbst & & 12.9 & \multirow[t]{2}{*}{ Developmental age } & \\
\hline 21 contr & & 11 & & \\
\hline Nelson et $\mathrm{al}^{24}$ & \multirow{4}{*}{$\begin{array}{l}\text { Randomly from Department of Orthodontics, } \\
\text { University of Otago (New Zealand) }\end{array}$} & & Cephalometric analysis & Minimum of 14 \\
\hline 12 act & & 11.6 & Height and weight & \\
\hline 13 FR-2 & & 11.6 & measurements & \\
\hline 17 contr & & 11.6 & & \\
\hline Tulloch et $\mathrm{al}^{25}$ & University of North Carolina & & Cephalometric analysis & Not declared \\
\hline 53 bio & & 9.4 & Hand-wrist radiographs & \\
\hline 61 contr & & 9.4 & & \\
\hline Illing et $\mathrm{al}^{26}$ & Waiting list & & Cephalometric analysis & Full time except for \\
\hline 13 Bass & & 12.5 & & meals and sports \\
\hline 18 bio & & 11.8 & & \\
\hline $16 \mathrm{~TB}$ & & 11.5 & & \\
\hline 20 contr & & 11.2 & & \\
\hline Franchi et $\mathrm{al}^{27}$ & UMESSGS & & Cephalometric analysis & Full time \\
\hline 55 Herbst & & 12.8 & Cervical vertebrae maturation & \\
\hline 30 contr & & 13.1 & analysis & \\
\hline Tümer and Gültan ${ }^{28}$ & Gazi University, Ankara, Turkey & & Cephalometric analysis & 16 \\
\hline 13 act & & 11.9 & Hand-wrist radiographs & Full time \\
\hline $13 \mathrm{~TB}$ & & 11.5 & & \\
\hline 13 contr & & 12.7 & & \\
\hline Toth and McNamara ${ }^{29}$ & UMESSGS & & Cephalometric analysis & Full time except for \\
\hline $40 \mathrm{~TB}$ & & 10.4 & & meals and sports \\
\hline 40 FR-2 & & 10.2 & & \\
\hline 40 contr & & 9.9 & & \\
\hline Mills and $\mathrm{McCulloch}{ }^{30}$ & Burlington Growth Centre, University of & & Cephalometric analysis & Full time \\
\hline $28 \mathrm{~TB}$ & Toronto & 9.1 & & \\
\hline 28 contr & & 9.1 & & \\
\hline Baccetti et $\mathrm{al}^{31}$ & UMESSGS & & Cephalometric analysis & Full time except for \\
\hline 21 TB early & & 9.9 & Cervical vertebrae maturation & meals and sports \\
\hline 16 ECG & & 9.1 & analysis & \\
\hline 15 TB late & & 12.9 & & \\
\hline $14 \mathrm{LCG}$ & & 13.6 & & \\
\hline Chadwick et al 32 & Patients declining FR-2 treatment & & Cephalometric analysis & Not declared \\
\hline 70 FR-2 & & 11.2 & & \\
\hline 68 contr & & 10.9 & & \\
\hline
\end{tabular}


Table III. Continued

\begin{tabular}{|c|c|c|c|}
\hline $\begin{array}{l}\text { Treatment/observation } \\
\text { duration (mo) }\end{array}$ & Success rate & $\begin{array}{l}\text { Posttreatment observation } \\
\quad(\text { duration-final age })\end{array}$ & Authors' conclusions \\
\hline 18 & Not declared & No & $\begin{array}{l}\text { Study does not support hypothesis that activator treatment } \\
\text { can affect condylar growth }\end{array}$ \\
\hline $\begin{array}{l}6 \\
6\end{array}$ & $100 \%$ & No & $\begin{array}{l}\text { Class II occlusal correction was mainly result of increase } \\
\text { in mandibular length and dentoalveolar modifications }\end{array}$ \\
\hline $\begin{array}{l}23 \\
25 \\
26 \\
22\end{array}$ & Not declared & No & $\begin{array}{l}\text { Principal skeletal effect was advancement of mandible } \\
\text { along direction of facial axis. This advancement } \\
\text { resulted in increases in mandibular length and vertical } \\
\text { facial dimensions }\end{array}$ \\
\hline $\begin{array}{l}32 \\
30 \\
25 \\
25\end{array}$ & Not declared & No & $\begin{array}{l}\text { Activator treatment has influence on skeletal structures of } \\
\text { face }\end{array}$ \\
\hline $\begin{array}{l}12 \\
21 \\
22\end{array}$ & Not declared & No & $\begin{array}{l}\text { Both appliances determine relevant dentoalveolar and } \\
\text { skeletal effects }\end{array}$ \\
\hline $\begin{array}{l}11.6 \\
12\end{array}$ & Not declared & No & $\begin{array}{l}\text { Mechanism of Class II correction with acrylic splint } \\
\text { Herbst involves enhancing mandibular growth }\end{array}$ \\
\hline $\begin{array}{l}18 \\
18 \\
18\end{array}$ & Not declared & No & $\begin{array}{l}\text { No evidence to support view that both appliances can } \\
\text { alter size of mandible }\end{array}$ \\
\hline $\begin{array}{l}15 \\
15\end{array}$ & $75 \%$ & No & $\begin{array}{l}\text { Functional appliance therapy produces greater mandibular } \\
\text { changes, but there is considerable variation in effect }\end{array}$ \\
\hline $\begin{array}{l}9 \\
9 \\
9 \\
9\end{array}$ & Not declared & No & $\begin{array}{l}\text { All appliances produced measurable change in skeletal } \\
\text { tissues, with untreated sample showing minimal change }\end{array}$ \\
\hline $\begin{array}{l}12 \\
12\end{array}$ & Not declared & $\begin{array}{c}\text { Yes }(2.3-15.1) \\
\text { Posttreatment includes fixed } \\
\text { appliances }\end{array}$ & $\begin{array}{l}\text { Significant favorable effects were assessed in total } \\
\text { mandibular length and ramus height increases }\end{array}$ \\
\hline $\begin{array}{r}10 \\
7 \\
14\end{array}$ & Not declared & No & $\begin{array}{l}\text { Stimulation of mandibular growth and correction of Class } \\
\text { II relationships were achieved }\end{array}$ \\
\hline $\begin{array}{l}16 \\
24 \\
23\end{array}$ & $100 \%$ & No & $\begin{array}{l}\text { FR-2 appears to have primarily skeletal effect; TB } \\
\text { produces both skeletal and dentoalveolar adaptations }\end{array}$ \\
\hline $\begin{array}{l}14 \\
13\end{array}$ & $100 \%$ & $\begin{array}{l}\text { Yes }(2.7-13.1) \\
1.5 \text { retention }\end{array}$ & $\begin{array}{l}2 / 3 \text { of overall mandibular length increase could be } \\
\text { attributed to increase in ramus height }\end{array}$ \\
\hline $\begin{array}{l}14 \\
16 \\
17 \\
15\end{array}$ & Not declared & No & $\begin{array}{l}\text { Clinically significant increments in total mandibular } \\
\text { length and ramus height when treatment includes } \\
\text { pubertal peak }\end{array}$ \\
\hline $\begin{array}{l}20 \\
22\end{array}$ & Not declared & No & $\begin{array}{l}\text { FR-2 does not produce clinically significant skeletal } \\
\text { changes }\end{array}$ \\
\hline
\end{tabular}


Table III. Continued

\begin{tabular}{|c|c|c|c|c|}
\hline Article material & Controls & Age $(y)$ & Methods/measurements & $\begin{array}{l}\text { Appliance wear } \\
\text { (h/day) }\end{array}$ \\
\hline de Almeida et $\mathrm{al}^{33}$ & \multirow{4}{*}{$\begin{array}{l}\text { File of longitudinal growth study of } \\
\text { University of Sao Paulo at Bauru }\end{array}$} & & \multirow[t]{4}{*}{ Cephalometric analysis } & \multirow[t]{4}{*}{24} \\
\hline 22 FR-2 & & 9 & & \\
\hline 22 bio & & 10.7 & & \\
\hline 22 contr & & 8.6 & & \\
\hline Basciftci et $\mathrm{al}^{34}$ & \multirow[t]{3}{*}{ Rejected orthodontic treatment } & & \multirow[t]{3}{*}{ Cephalometric analysis } & \multirow[t]{3}{*}{18} \\
\hline 50 act & & 12.6 & & \\
\hline 20 contr & & 12.6 & & \\
\hline Pangrazio-Kulbersh et $\mathrm{al}^{35}$ & \multirow[t]{3}{*}{ UMESSGS } & & \multirow[t]{3}{*}{ Cephalometric analysis } & \multirow[t]{3}{*}{ Full time } \\
\hline 30 MARA & & 11.2 & & \\
\hline 21 contr & & 11.1 & & \\
\hline Faltin et $\mathrm{al}^{36}$ & \multirow[t]{5}{*}{ UMESSGS } & & Cephalometric analysis & \multirow[t]{5}{*}{ Not declared } \\
\hline 13 bio early & & 9.7 & \multirow{4}{*}{$\begin{array}{l}\text { Cervical vertebrae maturation } \\
\text { analysis }\end{array}$} & \\
\hline 10 bio late & & 10.8 & & \\
\hline $11 \mathrm{ECG}$ & & 9.4 & & \\
\hline 10 LCG & & 11.2 & & \\
\hline Janson et $\mathrm{al}^{37}$ & Longitudinal growth study at Orthodontic & & \multirow[t]{3}{*}{ Cephalometric analysis } & \multirow[t]{3}{*}{ Not declared } \\
\hline 18 FR-2 & \multirow[t]{2}{*}{ Department, University of Sao Paulo } & 9.2 & & \\
\hline 23 contr & & 9.2 & & \\
\hline O'Brien et $\mathrm{al}^{38}$ & \multirow[t]{3}{*}{ National Health Service, United Kingdom } & & Cephalometric analysis & \multirow{3}{*}{$\begin{array}{l}\text { Full time except for } \\
\text { contact sports } \\
\text { and swimming }\end{array}$} \\
\hline 89 TВ & & 9.7 & \multirow{2}{*}{$\begin{array}{l}\text { Stage of maturation of cervical } \\
\text { spine analysis }\end{array}$} & \\
\hline 85 contr & & 9.8 & & \\
\hline Cozza et $\mathrm{al}^{39}$ & \multirow[t]{3}{*}{ Rejected orthodontic treatment } & & \multirow[t]{3}{*}{ Cephalometric analysis } & \multirow[t]{3}{*}{14} \\
\hline 40 act & & 10 & & \\
\hline 30 contr & & 10 & & \\
\hline
\end{tabular}

Act, Activator; Bass, Bass appliance; bio, bionator appliance; $F R$-2, function regulator of Fränkel; MARA, mandibular anterior repositioning appliance; $T B$, Twin-block appliance; contr, controls; $E C G$, early control group; $L C G$, late control group; $M$, male; $F$, female.

icant differences between treated and untreated groups. A statistically significant difference reported by a given study had to be greater than $2.0 \mathrm{~mm}$ to be regarded also as clinically significant. This threshold value for a clinically significant change was calculated on the basis of the average power of these studies.

Functional appliances produced a statistically significant annualized supplementary elongation in 23 of 33 samples for total mandibular length, in 12 of 17 samples for mandibular ramus height, and in 8 of 23 samples for mandibular body length. Outcomes in terms of changes in mandibular position in relation to the cranial base (SNB angle) were not clinically significant in any article except that of Tümer and Gültan, ${ }^{28}$ who found a clinically and statistically significant supplementary increase of $2.2^{\circ}$ per year (Table V).

When overall treatment duration was considered, 20 of 33 samples in the 22 studies described clinically significant supplementary growth with total mandibular length after active treatment in the treated group when compared with the untreated group.

The average coefficient of efficiency for functional jaw orthopedics (average amount of actual supplementary elongation of the mandible in treated subjects versus Class II controls after the overall treatment period divided by the number of months of treatment in each study) was $0.16 \mathrm{~mm}$ per month. The Herbst appliance, as reported in 4 samples, had a coefficient of efficiency of $0.28 \mathrm{~mm}$ per month. The coefficient for the Twin-block appliance was $0.23 \mathrm{~mm}$ per month, as reported in 7 samples. The coefficient for the bionator (0.17 mm per month) was equal to the average coefficient, as reported in 5 samples; for the activator, it was slightly lower ( $0.12 \mathrm{~mm}$ per month), as reported in 7 samples. The coefficient of efficiency for the Fränkel appliance, as reported in 8 samples, was the lowest (0.09 $\mathrm{mm}$ per month) (Table V).

\section{DISCUSSION \\ Quality of the studies}

RCTs have been used rarely in orthodontics, and this systematic review shows that studies on the outcomes of functional appliances are not an exception to this tendency. Among the reasons for the dearth of RCTs in orthodontics are the difficulty in gathering many patients with a specific occlusion deviation and the sensitive ethical issue of leaving a group of patients untreated. Furthermore, several items required in quality reviews ${ }^{10,11}$ - patients or observers blinded to treatment—clearly do not apply. These considerations led 
Table III. Continued

\begin{tabular}{|c|c|c|c|}
\hline $\begin{array}{l}\text { Treatment/observation } \\
\text { duration (mo) }\end{array}$ & Success rate & $\begin{array}{l}\text { Posttreatment observation } \\
\quad(\text { duration-final age })\end{array}$ & Authors' conclusions \\
\hline $\begin{array}{l}17 \\
16 \\
13\end{array}$ & Not declared & No & $\begin{array}{l}\text { Both appliances provide statistically significant increases } \\
\text { in mandibular growth and in degree of mandibular } \\
\text { protrusion }\end{array}$ \\
\hline $\begin{array}{l}16 \\
14\end{array}$ & Not declared & No & $\begin{array}{l}\text { Growth in mandibular length, ramus height, and corpus } \\
\text { length appeared significantly influenced by activator } \\
\text { treatment }\end{array}$ \\
\hline $\begin{array}{c}11 \\
\text { Not declared }\end{array}$ & Not declared & No & $\begin{array}{l}\text { MARA is effective in treating patients with Class II } \\
\text { malocclusion through dental and skeletal changes }\end{array}$ \\
\hline $\begin{array}{l}22 \\
28 \\
25 \\
21\end{array}$ & Not declared & $\begin{array}{c}\text { Yes (bio early, 7.7-17.4; } \\
\text { bio late, 8.3-19.1) } \\
\text { Posttreatment includes fixed } \\
\text { appliances }\end{array}$ & $\begin{array}{l}\text { Treatment protocol is effective and stable when it } \\
\text { includes pubertal growth spurt }\end{array}$ \\
\hline $\begin{array}{l}28 \\
28\end{array}$ & Not declared & No & $\begin{array}{l}\text { Most changes were dentoalveolar with fewer skeletal } \\
\text { changes }\end{array}$ \\
\hline $\begin{array}{l}15 \\
15\end{array}$ & Not declared & No & $\begin{array}{l}\text { Early functional treatment does not influence Class II } \\
\text { pattern to clinically significant degree }\end{array}$ \\
\hline $\begin{array}{l}21 \\
21\end{array}$ & Not declared & No & $\begin{array}{l}\text { Activator appliance is effective in treating mandibular } \\
\text { deficiency }\end{array}$ \\
\hline
\end{tabular}

to the inclusion of both prospective and retrospective longitudinal CCTs in this review. Efforts were often made by authors of CCTs to elevate the methodological soundness of their investigations. Three studies described outcomes in consecutively treated patients ${ }^{19,32,36}$; 1 study assigned patients randomly to compare treatment modalities ${ }^{26}$; 6 studies used nonhistorical Class II controls. ${ }^{19,21,28,32,34,39}$

In the quality analysis, 6 of the 22 studies were judged to be of medium/high quality (Table IV). Four of these 6 articles were RCTs. The reason for a medium/high quality score instead of a high score is that these studies had some methodological limitations. The article by O'Brien et $\mathrm{al}^{38}$ gaves no statistical analysis for the mandibular skeletal changes. The RCTs by Jakobsson, ${ }^{18}$ Nelson et al, ${ }^{24}$ and Tulloch et $\mathrm{al}^{25}$ did not use blinding in measuring the cephalometric parameters. On the other hand, $2 \mathrm{CCTs}^{26,32}$ were judged to be of medium/high quality, whereas most CCTs were judged to be of medium quality. The use of blinding in performing cephalometric analysis of craniofacial skeletal changes was the main factor that accounted for a higher score for these 2 CCTs. Only 3 of the 22 studies (Table IV) were considered of low quality because they lacked both method error analysis and blinding in measurements.

\section{Effectiveness, efficiency, and long-term effects of functional appliances on mandibular growth}

In this systematic review, the literature search aimed to select all RCTs and CCTs with untreated Class II controls that evaluated treatment outcomes of functional jaw orthopedics in Class II malocclusion. Four RCTs were found. Eighteen CCTs evaluated the effects of functional appliances versus no treatment, and they showed controversial results in terms of quantitative change in mandibular dimensions. All studies agreed in pointing out that mandibular position to the cranial base as measured by the SNB angle was not impacted in a clinically significant way by functional jaw orthopedics, with the exception of that by Tümer and Gültan. ${ }^{34}$ The SNB angle is a poor indicator of the effectiveness of functional jaw orthopedics. In most patients, the initial correction of a Class II relationship involves not just posturing the mandible in a forward position; vertical opening of the bite typically is involved, and a deep overbite is corrected. A millimeter of increased lower anterior facial height camouflages a millimeter of 
Table IV. Quality evaluation of studies

\begin{tabular}{|c|c|c|c|c|c|c|}
\hline Article sample size & $\begin{array}{c}\text { Previous estimate } \\
\text { of sample size }\end{array}$ & Withdrawals & $\begin{array}{c}\text { Method error } \\
\text { analysis }\end{array}$ & $\begin{array}{l}\text { Blinding in } \\
\text { measurements }\end{array}$ & $\begin{array}{l}\text { Adequate } \\
\text { statistics } \\
\text { provided }\end{array}$ & $\begin{array}{l}\text { Judged } \\
\text { quality } \\
\text { standard }\end{array}$ \\
\hline Jakobsson $^{18}$ & Yes & & Yes & No & $\mathrm{No}^{*}$ & Medium/high \\
\hline 17 act & & 3 act & & & & \\
\hline 17 contr & & 2 contr & & & & \\
\hline $\begin{array}{c}\text { Pancherz }^{19} \\
22 \text { Herbst } \\
20 \text { contr }\end{array}$ & No/unknown & None & Yes & No & No* & Medium \\
\hline $\begin{array}{l}\text { McNamara et } \mathrm{al}^{20} \\
51 \text { FR-2 early } \\
49 \text { FR-2 late } \\
36 \text { ECG } \\
21 \text { LCG }\end{array}$ & No/unknown & None & No & No & No* & Low \\
\hline $\begin{array}{l}\text { Jakobsson and Paulin }^{21} \\
22 \text { act } \mathrm{M} \\
31 \text { act } \mathrm{F} \\
28 \text { contr } \mathrm{M} \\
32 \text { contr } \mathrm{F}\end{array}$ & No/unknown & None & Yes & No & $\mathrm{No}^{*}$ & Medium \\
\hline $\begin{array}{l}\text { McNamara et } \mathrm{al}^{22} \\
45 \text { Herbst } \\
41 \text { FR-2 } \\
21 \text { contr }\end{array}$ & No/unknown & None & Yes & No & No* & Medium \\
\hline $\begin{array}{l}\text { Windmiller }{ }^{23} \\
46 \text { Herbst } \\
21 \text { contr }\end{array}$ & No/unknown & None & No & No & $\mathrm{No}^{*}$ & Low \\
\hline $\begin{array}{l}\text { Nelson et } \mathrm{al}^{24} \\
12 \text { act } \\
13 \text { FR-2 } \\
3 \text { FR-2 } \\
17 \text { contr }\end{array}$ & Yes & $\begin{array}{l}5 \text { act } \\
3 \text { FR-2 }\end{array}$ & Yes & No & $\mathrm{No}^{*}$ & Medium/high \\
\hline $\begin{array}{l}\text { Tulloch et } \mathrm{al}^{25} \\
53 \text { bio } \\
61 \text { contr }\end{array}$ & Yes & 9 & Yes & No & Yes & Medium/high \\
\hline Illing et $\mathrm{a}^{26}$ & No/unknown & & Yes & Yes & Yes & Medium/high \\
\hline 13 Bass & & 5 Bass & & & & \\
\hline 18 bio & & 3 bio & & & & \\
\hline $16 \mathrm{~TB}$ & & $3 \mathrm{~TB}$ & & & & \\
\hline 20 contr & & 0 contr & & & & \\
\hline $\begin{array}{c}\text { Franchi et al }{ }^{27} \\
55 \text { Herbst } \\
30 \text { contr }\end{array}$ & No/unknown & None & Yes & No & Yes & Medium \\
\hline $\begin{array}{l}\text { Tümer and Gültan }{ }^{28} \\
13 \text { act } \\
13 \text { TB } \\
13 \text { contr }\end{array}$ & No/unknown & None & No & No & No* & Low \\
\hline $\begin{array}{l}\text { Toth and McNamara }{ }^{29} \\
40 \text { TB } \\
40 \text { FR-2 } \\
40 \text { contr }\end{array}$ & No/unknown & None & Yes & No & No* & Medium \\
\hline $\begin{array}{l}\text { Mills and McCulloch } \\
28 \mathrm{~TB} \\
28 \text { contr }\end{array}$ & No/unknown & None & Yes & No & No* & Medium \\
\hline $\begin{array}{l}\text { Baccetti et al }^{31} \\
21 \text { TB early } \\
16 \text { ECG } \\
15 \text { TB late } \\
14 \text { LCG }\end{array}$ & No/unknown & None & Yes & No & Yes & Medium \\
\hline
\end{tabular}


Table IV. Continued

\begin{tabular}{|c|c|c|c|c|c|c|}
\hline Article sample size & $\begin{array}{l}\text { Previous estimate } \\
\text { of sample size }\end{array}$ & Withdrawals & $\begin{array}{l}\text { Method error } \\
\text { analysis }\end{array}$ & $\begin{array}{l}\text { Blinding in } \\
\text { measurements }\end{array}$ & $\begin{array}{l}\text { Adequate } \\
\text { statistics } \\
\text { provided }\end{array}$ & $\begin{array}{c}\text { Judged } \\
\text { quality } \\
\text { standard }\end{array}$ \\
\hline $\begin{array}{l}\text { Chadwick et al }{ }^{32} \\
70 \text { FR-2 } \\
68 \text { contr }\end{array}$ & No/unknown & None & Yes & Yes & Yes & Medium/high \\
\hline $\begin{array}{l}\text { de Almeida et al }{ }^{33} \\
22 \text { FR-2 } \\
22 \text { bio } \\
22 \text { contr }\end{array}$ & No/unknown & None & Yes & No & No* & Medium \\
\hline $\begin{array}{l}\text { Basciftci et } \mathrm{al}^{34} \\
50 \text { act } \\
20 \text { contr }\end{array}$ & No/unknown & None & Yes & No & No* & Medium \\
\hline $\begin{array}{l}\text { Pangrazio-Kulbersh } \\
\text { et al }^{35} \\
30 \text { MARA } \\
21 \text { contr }\end{array}$ & No/unknown & None & Yes & No & No* & Medium \\
\hline $\begin{array}{l}\text { Faltin et al }{ }^{36} \\
13 \text { bio early } \\
10 \text { bio late } \\
11 \text { ECG } \\
10 \text { LCG }\end{array}$ & No/unknown & None & Yes & No & Yes & Medium \\
\hline $\begin{array}{c}\text { Janson et } \mathrm{al}^{37} \\
18 \text { FR-2 } \\
23 \text { contr }\end{array}$ & No/unknown & None & Yes & No & Yes & Medium \\
\hline $\begin{array}{l}\mathrm{O}^{\prime} \text { Brien et } \mathrm{al}^{38} \\
89 \mathrm{~TB} \\
85 \text { contr }\end{array}$ & Yes & $\begin{array}{l}14 \mathrm{~TB} \\
1 \text { contr }\end{array}$ & Yes & Yes & $\begin{array}{l}\text { No (no statistical } \\
\text { analysis of } \\
\text { mandibular } \\
\text { skeletal } \\
\text { changes) }\end{array}$ & Medium/high \\
\hline $\begin{array}{c}\text { Cozza et al }{ }^{39} \\
40 \text { act } \\
30 \text { contr }\end{array}$ & No/unknown & None & Yes & No & Yes & Medium \\
\hline
\end{tabular}

Act, Activator; Bass, Bass appliance; bio, bionator appliance; $F R$-2, function regulator of Fränkel; MARA, mandibular anterior repositioning appliance; $T B$, Twin-block appliance; contr, controls; $E C G$, early control group; $L C G$, late control group; $M$, male; $F$, female.

*Use of parametric tests in samples that were not tested for normality.

increased mandibular length, ${ }^{5}$ so the advancement of the chin point at pogonion might not be evident if the vertical dimension is increased along with mandibular length.

The amount of supplementary growth of the mandible when compared with untreated Class II controls varied widely among the studies. With regard to the changes in total mandibular length (measured by Co-Gn or Co-Pg), two-thirds of the samples in these studies described clinically significant supplementary growth after active treatment in the treated group when compared with the untreated group.

Interestingly enough, none of the 4 RCTs reported a clinically significant change in mandibular length induced by functional appliances. To further explain this finding, the influence of treatment timing (skeletal maturity at the start of functional therapy) on treatment results should be analyzed. It has previously been demonstrated that the effectiveness of functional treatment of mandib- ular growth deficiencies strongly depends on the biological responsiveness of the condylar cartilage, which in turn depends on the growth rate of the mandible (expressed as prepeak, peak, and postpeak growth rates with regard to the pubertal growth spurt). ${ }^{40-42}$ Only $7^{19,25,27,28,31,36,38}$ of the 22 studies in this review reported information about their subjects' skeletal maturity with a biological indicator (eg, hand-wrist analysis, cervical vertebral maturation method). In these 7 studies, 10 samples of patients treated with functional appliances were investigated: 4 samples ${ }^{25,31,36,38}$ received treatment before the pubertal peak in skeletal growth, whereas, in 6 samples, ${ }^{19,27,28,31,36,38}$ treatment included the pubertal peak. The amount of actual supplementary mandibular growth induced by treatment (measured by Co-Gn or Co-Pg) was clinically significant $(>2.0 \mathrm{~mm})$ in all the "peak" samples, except those reported by Tümer and Gültan $^{34}$ (1.5 and $1.4 \mathrm{~mm}$ in the samples treated with the activator and the Twin-block, respectively). How- 
Table V. Descriptive analysis of reported outcomes

\begin{tabular}{|c|c|c|c|c|c|c|c|c|}
\hline \multirow[b]{2}{*}{ Articles } & \multirow[b]{2}{*}{ Appliance } & \multirow[b]{2}{*}{$\begin{array}{c}\text { Active } \\
\text { treatment } \\
\text { duration }(\mathrm{mo})\end{array}$} & \multicolumn{4}{|c|}{ Annualized changes } & \multicolumn{2}{|c|}{ Actual change } \\
\hline & & & $S N B$ & $\begin{array}{c}\mathrm{Co}-\mathrm{Gn} \\
\text { (or } \mathrm{Co}-\mathrm{Pg} \text { ) } \\
\quad \mathrm{mm}\end{array}$ & Co-Go mm & $\begin{array}{c}\text { Go-Gn } \\
\text { (or Go-Me; or } \\
\text { Go-Pg) mm }\end{array}$ & $\begin{array}{c}\text { Co-Gn } \\
\text { (or } \mathrm{Co}-\mathrm{Pg} \text { ) } \\
\mathrm{mm}\end{array}$ & $\begin{array}{l}\text { Coefficient of } \\
\text { efficiency } \\
(\mathrm{mm} / \mathrm{mo})\end{array}$ \\
\hline Jakobsson $^{18}$ & act & 18 & - & $0.5(\mathrm{NS})$ & - & - & 0.7 & 0.04 \\
\hline Pancherz $^{19}$ & Herbst & $6^{*}$ & $1.4^{\ddagger}$ & $2.2(\mathrm{~S})^{\dagger}$ & - & - & $2.2^{\dagger}$ & 0.37 \\
\hline \multirow[t]{2}{*}{ McNamara et $\mathrm{al}^{20}$} & FR-2 E & 24 & $0.3(\mathrm{~S})$ & $1.2(\mathrm{~S})$ & $1.0(\mathrm{~S})$ & $0.0(\mathrm{NS})$ & 2.4 & 0.10 \\
\hline & FR-2 L & 24 & $0.4(\mathrm{~S})$ & $1.8(\mathrm{~S})$ & $1.5(\mathrm{~S})$ & $0.1(\mathrm{NS})$ & 3.6 & 0.15 \\
\hline \multirow{2}{*}{$\begin{array}{c}\text { Jakobsson and } \\
\text { Paulin }^{21}\end{array}$} & act $\mathrm{M}$ & 32 & $0.6(S)$ & $1.2(\mathrm{~S})$ & - & - & 3.2 & 0.10 \\
\hline & act $F$ & 30 & 0.1 (NS) & $0.2(\mathrm{NS})$ & - & - & 0.5 & 0.02 \\
\hline \multirow[t]{2}{*}{ McNamara et $\mathrm{al}^{22}$} & Herbst & 12 & $1.6(\mathrm{~S})$ & $2.7(\mathrm{~S})$ & $2.1(\mathrm{~S})$ & $0.2(\mathrm{NS})$ & 2.7 & 0.22 \\
\hline & FR-2 & 21 & $0.5(\mathrm{NS})$ & $2.2(\mathrm{~S})$ & $1.8(\mathrm{~S})$ & $0.3(\mathrm{NS})$ & 3.8 & 0.18 \\
\hline Windmiller ${ }^{23}$ & Herbst & 12 & $1.3(\mathrm{~S})$ & $3.5(\mathrm{~S})$ & $2.9(\mathrm{~S})$ & 0.3 (NS) & 3.5 & 0.30 \\
\hline \multirow[t]{2}{*}{ Nelson et $\mathrm{al}^{24}$} & FR-2 & 18 & $0.2(\mathrm{NS})$ & 0.5 (NS) & $0.0(\mathrm{NS})$ & 0.7 (NS) & 0.7 & 0.04 \\
\hline & act & 18 & $0.2(\mathrm{NS})$ & 0.9 (NS) & $-0.7(\mathrm{NS})$ & $1.2(\mathrm{~S})$ & 1.3 & 0.07 \\
\hline Tulloch et $\mathrm{al}^{25}$ & bo & 15 & $0.6(\mathrm{~S})$ & $1.3(\mathrm{~S})$ & - & - & 1.6 & 0.11 \\
\hline \multirow[t]{3}{*}{ Illing et $\mathrm{a}^{26}$} & Bass & 9 & $1.5(\mathrm{NS})$ & 0.5 (NS) & - & - & 0.4 & 0.04 \\
\hline & bio & 9 & $1.1(\mathrm{NS})$ & $3.5(\mathrm{~S})$ & - & - & 2.6 & 0.29 \\
\hline & TB & 9 & $1.3(\mathrm{NS})$ & $3.2(\mathrm{~S})$ & - & - & 2.4 & 0.27 \\
\hline Franchi et $\mathrm{al}^{27}$ & Herbst & 12 & - & $2.7(\mathrm{~S})$ & $1.2(\mathrm{~S})$ & $1.1(\mathrm{NS})$ & 2.7 & 0.22 \\
\hline \multirow[t]{2}{*}{ Tümer and Gültan ${ }^{28}$} & act & 10 & $2.2(\mathrm{~S})$ & $1.8(\mathrm{~S})$ & - & $0.2(\mathrm{NS})$ & 1.5 & 0.15 \\
\hline & TB & $7 *$ & $1.5(\mathrm{~S})$ & $1.4(\mathrm{~S})$ & - & -0.5 (NS) & 1.4 & 0.20 \\
\hline \multirow{2}{*}{$\begin{array}{l}\text { Toth and } \\
\text { McNamara }^{29}\end{array}$} & TB & 16 & $1.0(\mathrm{~S})$ & $2.2(\mathrm{~S})$ & $1.3(\mathrm{~S})$ & $0.7(\mathrm{~S})$ & 3.0 & 0.19 \\
\hline & FR-2 & 24 & 0.3 (NS) & $1.4(\mathrm{~S})$ & $1.0(\mathrm{~S})$ & 0.1 (NS) & 2.8 & 0.12 \\
\hline \multicolumn{9}{|l|}{ Mills and } \\
\hline $\mathrm{McCulloch}^{30}$ & $\mathrm{~TB}$ & 14 & $1.9(\mathrm{~S})$ & $3.6(\mathrm{~S})$ & $2.5(\mathrm{~S})$ & $1.1(\mathrm{~S})$ & 4.2 & 0.30 \\
\hline \multirow[t]{2}{*}{ Baccetti et $a^{31}$} & TB E & 14 & - & $1.9(\mathrm{~S})$ & $0.3(\mathrm{NS})$ & $1.0(\mathrm{NS})$ & 2.2 & 0.16 \\
\hline & TB L & 17 & - & $4.7(S)$ & $2.7(\mathrm{~S})$ & $1.7(\mathrm{~S})$ & 6.7 & 0.39 \\
\hline \multirow{3}{*}{$\begin{array}{l}\text { Chadwick et } \mathrm{al}^{32} \\
\text { de Almeida et } \mathrm{al}^{33}\end{array}$} & FR-2 & 20 & $0.4(\mathrm{~S})$ & $0.3(\mathrm{NS})$ & - & - & 0.6 & 0.03 \\
\hline & bio & 16 & $1.3(\mathrm{~S})$ & $1.7(\mathrm{~S})$ & - & $1.1(\mathrm{~S})$ & 2.3 & 0.14 \\
\hline & FR-2 & 17 & $0.4(\mathrm{NS})$ & $0.8(\mathrm{~S})$ & - & $0.8(\mathrm{~S})$ & 1.2 & 0.07 \\
\hline Basciftci et $\mathrm{al}^{34}$ & act & 16 & 0.7 (NS) & $3.9(\mathrm{~S})$ & - & $2.2(\mathrm{~S})$ & 5.2 & 0.32 \\
\hline $\begin{array}{l}\text { Pangrazio-Kulbersh } \\
\text { et } \mathrm{al}^{35}\end{array}$ & MARA & 11 & $1.0(\mathrm{~S})$ & $2.7(\mathrm{~S})$ & $2.7(\mathrm{~S})$ & $0.1(\mathrm{NS})$ & 2.7 & 0.23 \\
\hline \multirow[t]{2}{*}{ Faltin et $\mathrm{a}^{36}$} & bio & 22 & - & 0.4 (NS) & 0.0 (NS) & 0.2 (NS) & 1.9 & 0.09 \\
\hline & bio & 28 & - & $2.1(\mathrm{~S})$ & $2.1(\mathrm{~S})$ & $0.0(\mathrm{NS})$ & 4.3 & 0.15 \\
\hline Janson et $\mathrm{al}^{37}$ & FR-2 & 28 & $1.4(\mathrm{NS})$ & $0.0(\mathrm{NS})$ & 0.1 (NS) & $0.7(\mathrm{~S})$ & 0.5 & 0.02 \\
\hline O'Brien et $\mathrm{al}^{38}$ & $\mathrm{~TB}$ & 15 & - & $1.2^{\dagger, \#}$ & - & - & 1.5 & 0.10 \\
\hline Cozza et $\mathrm{al}^{39}$ & act & 21 & $0.8(\mathrm{~S})$ & $1.5(\mathrm{NS})$ & - & $0.1(\mathrm{NS})$ & 2.7 & 0.13 \\
\hline
\end{tabular}

Act, Activator; Bass, Bass appliance; bio, bionator appliance; $F R$-2, function regulator of Fränkel; MARA, mandibular anterior repositioning appliance; $T B$, Twin-block appliance; contr, controls; $E C G$, early control group; $L C G$, late control group; $M$, male; $F$, female; $S$, statistically significant; $N S$, not significant as reported by authors.

Statistically and clinically significant differences (at least $2 \mathrm{~mm}$ ) shown in bold and italics.

*Outcomes were not annualized.

${ }^{\dagger}$ Measured as Pg/OLp + Co/OLp.

${ }^{*}$ Not evaluated statistically by author.

ever, the average active treatment duration for both samples in that study was about half that reported by the other studies in this review for the same type of appliances. None of the samples treated in the prepeak period had a clinically significant amount of supplementary mandibular growth. The inclusion of the pubertal growth spurt in the treatment period can be regarded as a key factor in the attainment of clinically significant supplementary mandibular growth with functional jaw orthopedics. This observation corrobo- rates previous research and emphasizes the role of treatment timing on treatment outcomes for functional appliances. ${ }^{40-42}$

With regard to treatment timing as reported by the RCTs, 2 of them did not include an adequate appraisal of skeletal maturity, ${ }^{18,24}$ whereas both Tulloch et $\mathrm{al}^{25}$ and O'Brien et $\mathrm{al}^{38}$ described the results of functional appliances used at prepeak stages. The lack of clinical significance in the outcomes of these 2 RCTs might correlate with the prepubertal treatment timing of the 
reported samples. Similarly, the RCT by Jakobsson ${ }^{18}$ reported outcomes of activator treatment at an average age of 8.5 years (a very early age for the peak in mandibular growth). An RCT on the effects of the functional appliances used at the pubertal growth spurt is needed.

Different functional appliances require different treatment durations to reach the goal of correcting a Class II malocclusion at the occlusal level. It was interesting, therefore, to appraise the efficiency of different types of functional appliances in inducing a supplementary elongation of the mandible with respect to controls. Efficiency was appraised by dividing the supplementary elongation of the mandible obtained during the overall treatment period with the functional appliance by the number of months of active treatment (coefficient of efficiency). The average coefficient of efficiency for functional jaw orthopedics was $0.16 \mathrm{~mm}$ per month, with an average duration of active treatment of approximately 17 months. The Herbst appliance had the highest coefficient of efficiency $(0.28 \mathrm{~mm}$ per month) followed by the Twin-block $(0.23 \mathrm{~mm}$ per month). Both the bionator and the activator had intermediate scores of efficiency $(0.17$ and $0.12 \mathrm{~mm}$ per month, respectively). The Fränkel appliance had the least efficiency $(0.09 \mathrm{~mm}$ per month).

Only 1 of the 22 studies described changes observed in the posttreatment period until completion of growth to verify whether the gain in mandibular length achieved during active treatment was maintained. ${ }^{36}$ The long-term study by Faltin et $\mathrm{al}^{36}$ reported the effects of Class II treatment with the bionator about 8 years after active therapy (average age, about 18 years). The posttreatment period comprised a short phase with fixed appliances to refine occlusion (without Class II elastics). In the long term, the "early-treated" sample (bionator treatment before the peak in mandibular growth) did not show significant differences in mandibular growth when compared with the controls with the same skeletal maturity $(1.9 \mathrm{~mm})$. On the contrary, a statistically and clinically significant amount of supplementary mandibular growth $(5.1 \mathrm{~mm})$ was observed in the group treated during the pubertal growth spurt with respect to the controls. These results should be considered cautiously because of the restrospective nature of the study and the limited number of subjects in the samples. Two other studies $^{27,30}$ reported a posttreatment observation (Table III) that, however, was not considered valid for an appraisal of actual outcomes in the long term because the final age of the patients at the posttreatment observation was less than 16 years.

\section{CONCLUSIONS}

This study was undertaken to answer the question "Does the mandible grow more in Class II subjects treated with functional appliances than in untreated Class II subjects?" Corollaries included "Is the average effect of functional appliances on mandibular length clinically significant?" and "Which functional appliances are more efficient?"

On the basis of the analysis of 22 retrieved articles, it can be concluded that:

1. The quality standard of these investigations ranged from low to medium/high. Four RCTs were available, and 2 CCTs showed methodological soundness higher than average. Three of the 22 studies were judged of low quality.

2. Two-thirds of the samples in the 22 studies reported clinically significant supplementary elongation in total mandibular length as a result of overall active treatment with functional appliances.

3. The short-term amount of supplementary mandibular growth appears to be significantly larger when the functional treatment is performed at the adolescent growth spurt.

4. None of the 4 RCTs reported clinically significant supplementary growth of the mandible induced by functional appliances. When analyzed in terms of treatment timing, 3 of the 4 RCTs described outcomes of treatment at a prepubertal stage of skeletal maturity.

5. The Herbst appliance showed the highest coefficient of efficiency $(0.28 \mathrm{~mm}$ per month) followed by the Twin-block ( $0.23 \mathrm{~mm}$ per month).

For a commentary and author's response to this article, visit www.mosby.com/AJODO.

\section{REFERENCES}

1. Kelly JE, Harvey C. An assessment of the teeth of youths 12-17 years. DHEW Publication No (HRA) 77-1644. Washington, DC: National Center for Health Statistics; 1977.

2. McLain JB, Proffit WR. Oral health status in the United States: prevalence of malocclusion. J Dent Educ 1985;49:386-96.

3. Proffit WR, Fields HW, Moray LJ. Prevalence of malocclusion and orthodontic treatment need in the United States: estimates from the N-HANES III survey. Int J Adult Orthod Orthog Surg 1998;13:97-106.

4. McNamara JA Jr. Components of a Class II malocclusion in children 8-10 years of age. Angle Orthod 1981;51:177-202.

5. McNamara JA Jr, Brudon WL. Orthodontics and dentofacial orthopedics. Ann Arbor: Needham Press; 2001. p. 67-80.

6. McNamara JA Jr. Neuromuscular and skeletal adaptations to altered function in the orofacial region. Am J Orthod 1973;64: 578-606. 
7. McNamara JA Jr, Carlson DS. Quantitative analysis of temporomandibular joint adaptations to protrusive function. Am J Orthod 1979;76:593-609.

8. Xiong H, Hägg U, Tang G-H, Rabie ABM, Robinson W. The effect of continuous bite-jumping in adult rats: a morphological study. Angle Orthod 2004;74:86-92.

9. Chen JY, Will LA, Niederman R. Analysis of efficacy of functional appliances on mandibular growth. Am J Orthod Dentofacial Orthop 2002;122:470-6.

10. Antczak AA, Tang J, Chalmers TC. Quality assessment of randomized control trials in dental research I. Methods. J Periodont Res 1986;21:305-14.

11. Jadad AR, Moore RA, Carroll D, Jenkinson C, Reynolds DJ, Gavaghan DJ, et al. Assessing the quality of reports of randomized clinical trials: is blinding necessary? Control Clin Trials 1996;17:1-12.

12. Petrán S, Bondemark L, Söderfeldt B. A systematic review concerning early orthodontic treatment of unilateral posterior crossbite. Angle Orthod 2003;73:588-96.

13. Harris E. A cephalometric analysis of mandibular growth rate. Am J Orthod 1962;48:161-73.

14. Buschang PH, Tanguay R, Turkewicz J, Demirjian A, La Palme L. A polynomial approach to craniofacial growth: description and comparison of adolescent males with normal occlusion and those with untreated Class II malocclusion. Am J Orthod Dentofacial Orthop 1986;90:437-42.

15. Buschang PH, Tanguay R, Demirjian A, LaPalme L, Turkewicz J. Mathematical models of longitudinal mandibular growth for children with normal and untreated Class II, Division 1 malocclusion. Eur J Orthod 1988;10:227-34.

16. Alderson P, Green S, Higgins JPT, editors. Formulating the problem. Cochrane Reviewers' Handbook 4.2.2 [updated December 2003]; Section 4. http://www.cochrane.org/resources/ handbook/hbook.htm (accessed January 30, 2005).

17. Phillips C. Sample sizes and power: what is enough? Semin Orthod 2002;8:67-76.

18. Jakobsson S. Cephalometric evaluation of treatment effect on Class II, Division 1 malocclusion. Am J Orthod 1967;53:446-56.

19. Pancherz H. The mechanism of Class II correction in Herbst appliance treatment. A cephalometric investigation. Am J Orthod 1982;82:104-13.

20. McNamara JA Jr, Bookstein FL, Shaughnessy TG. Skeletal and dental changes following functional regulator therapy on Class II patients. Am J Orthod 1985;88:91-110.

21. Jakobsson S-O, Paulin G. The influence of activator on skeletal growth in Angle Class II:1 cases. A roentgenocephalometric study. Eur J Orthod 1990;12:174-84.

22. McNamara JA Jr, Howe RP, Dischinger TG. A comparison of the Herbst and Fränkel appliances in the treatment of Class II malocclusion. Am J Orthod Dentofacial Orthop 1990;98:134-44.

23. Windmiller EC. The acrylic-splint Herbst appliance: a cephalometric evaluation. Am J Orthod Dentofacial Orthop 1993;104: 73-84.

24. Nelson C, Harkness M, Herbison P. Mandibular changes during functional appliance treatment. Am J Orthod Dentofacial Orthop 1993;104:153-61.

25. Tulloch JFC, Phillips C, Koch G, Proffit WR. The effect of early intervention on skeletal pattern in Class II malocclusion: a randomized clinical trial. Am J Orthod Dentofacial Orthop 1997;111:391-400
26. Illing HM, Morris DO, Lee RT. A prospective evaluation of Bass, Bionator and Twin Block appliances. Part I-the hard tissues. Eur J Orthod 1998;20:501-16.

27. Franchi L, Baccetti T, McNamara JA Jr. Treatment and posttreatment effects of acrylic splint Herbst appliance therapy. Am J Orthod Dentofacial Orthop 1999;115:429-38.

28. Tümer N, Gültan S. Comparison of the effects of monobloc and Twin-block appliances on the skeletal and dentoalveolar structures. Am J Orthod Dentofacial Orthop 1999;116:460-8.

29. Toth LR, McNamara JA Jr. Treatment effects produced by the Twin-block appliance and the FR-2 appliance of Fränkel compared with an untreated Class II sample. Am J Orthod Dentofacial Orthop 1999;116:597-609.

30. Mills CM, McCulloch KJ. Posttreatment changes after successful correction of Class II malocclusions with the Twin-block appliance. Am J Orthod Dentofacial Orthop 2000;118:24-33.

31. Baccetti T, Franchi L, Toth LR, McNamara JA Jr. Treatment timing for Twin-block therapy. Am J Orthod Dentofacial Orthop 2000;118:159-70.

32. Chadwick SM, Aird JC, Taylor PJS, Bearn DR. Functional regulator treatment of Class II Division 1 malocclusions. Eur J Orthod 2001;23:495-505.

33. de Almeida MR, Henriques JFC, Ursi W. Comparative study of Fränkel (FR-2) and bionator appliances in the treatment of Class II malocclusion. Am J Orthod Dentofacial Orthop 2002;121:458-66.

34. Basciftci FA, Uysal TU, Büyükerkmen A, Sari Z. The effects of activator treatment on the craniofacial structures of Class II Division 1 patients. Eur J Orthod 2003;25:87-93.

35. Pangrazio-Kulbersh V, Berger JL, Chermak DS, Kaczynski R, Simon ES, Haerian A. Treatment effects of the mandibular anterior repositioning appliance on patients with Class II malocclusion. Am J Orthod Dentofacial Orthop 2003;123:286-95.

36. Faltin K Jr, Faltin RM, Baccetti T, Franchi L, Ghiozzi B, McNamara JA Jr. Long-term effectiveness and treatment timing for bionator therapy. Angle Orthod 2003;73:221-30.

37. Janson GRP, Toruno JLA, Martins DR, Henriques JFC, de Freitas MR. Class II treatment effects of the Fränkel appliance. Eur J Orthod 2003;25:301-9.

38. O’Brien K, Wright J, Conboy F, Sanjie Y, Mandall N, Chadwick $\mathrm{S}$, et al. Effectiveness of early orthodontic treatment with the Twin-block appliance: a multicenter, randomized, controlled trial. Part I: dental and skeletal effects. Am J Orthod Dentofacial Orthop 2003;124:234-43.

39. Cozza P, De Toffol L, Colagrossi S. Dentoskeletal effects and facial profile changes during activator therapy. Eur J Orthod 2004;26:293-302

40. Hägg U, Pancherz H. Dentofacial orthopaedics in relation to chronological age, growth period and skeletal development. An analysis of 72 male patients with Class II Division 1 malocclusion treated with the Herbst appliance. Eur J Orthod 1988;10: 169-76.

41. Malmgren O, Ömblus J, Hägg U, Pancherz H. Treatment with an appliance system in relation to treatment intensity and growth periods. Am J Orthod Dentofacial Orthop 1987;91:143-51.

42. Petrovic A, Stutzmann J, Lavergne J. Mechanism of craniofacial growth and modus operandi of functional appliances: a cell-level and cybernetic approach to orthodontic decision making. In: Carlson DS, editor. Craniofacial growth theory and orthodontic treatment. Monograph 23. Craniofacial Growth Series. Ann Arbor: Center for Human Growth and Development; University of Michigan; 1990. p. 13-74. 